\title{
PEMIKIRAN LUDWIG WITTGENSTEIN TENTANG EKSISTENSI TUHAN
}

\author{
Anisa Listiana \\ STAIN Kudus Jawa Tengah \\ Anisa_listi@gmail.com
}

\begin{abstract}
Abstrak
Tulisan ini mengkaji pemikiran Ludwig Wittgenstein tentang eksistensi Tuhan. Pokok masalah difokuskan pada upaya mengungkap bagaimana seting historis Witgenstein, bagaimana pemikirannya dan implikasi pemikirannya. Kajian ini menggunakan pendekatan historis filosofis, dengan tujuan untuk mengidentifikasi konsep pemikiran Witgenstein tentang eksistensi Tuhan berikut historisitas pemikirannya. Dalam usahanya mengetahui Tuhan, Witgenstein menggunakan pendekatan filsafat bahasa. Witgenstein beranggapan bahwa setiap hal yang dipikirkan harus pula dapat diucapkan. Ketika kita berbicara tentang bahasa sebagai ekspresi pengucapan pikiran, demkian Wittgenstein, maka pembatasan bahasa juga berarti pembatasan pikiran. Dari sini ia kemudian melihat bahwa pengalaman mistik merupakan pengalaman yang hanya dapat ditunjuk dan dialami, tetapi kita tidak bisa berbicara tentangnya karena bahasa kita sendiri juga sifatnya terbatas. Sesuatu yang berbau metafisika, seperti Tuhan menurutnya adalah mistik dan tidak perlu ditafsirkan, karena Tuhan bukanlah obyek fisik yang terbatas, Tuhan bukanlah sebuah nama barang, Tuhan merupakan semangat dan bukan fisik. Pemikiran Witgenstein semacam ini pada gilirannya telah melahirkan aliran positivisme logis.
\end{abstract}

Abstract

THE EXISTENCE OF GOD IN THE VIEW OF LUDWIG WITTGENSTEIN. This article explores the ideas of Ludwig Wittgenstein about the existence of God. The main focus is centered on the historical setting of his life, his thoughts and the implications of his thoughts. This study uses historical philosophical approach, aiming to identify the conception of God's existence in the view of Witgenstein, including the historicity of his thinkings. In his quest 
to know God, Witgenstein uses the philosophy of language approach. He assumes that everything that can be thought should also be pronounced. When we talk about the pronunciation of the language as an expression of the mind, he asserts, language restriction also means restriction of mind. He then furtherly elaborates that the mystical experience is an experience that can only be appointed and experienced, but we can not talk about it because of our language limitation. Something metaphysical, as God, is mystical and not to be interpreted because God is not limited to physical objects, God is not a name of thing: God is a spirit and not physical. This kind of thinkings of Witgenstein, in turn, has given rise to the logical positivism.

Kata Kunci: Language Game; Picture Teory; Existence of God

\section{A. Pendahuluan}

Dalam sejarah perkembangan filsafat sejak zaman pra Yunani kuno sampai pada abad XX sekarang ini, telah banyak aliran filsafat yang bermunculan. Setiap aliran mempunyai karakteristik sesuai dengan pendapat dan metode yang dimunculkan dalam rangka mencari kebenaran. Untuk mempertahankan pendapat dan metodenya tidak jarang para filosof saling menimbulkan pertentangan, sehingga muncul aliran filsafat baru sebagai reaksi dari filsafat sebelumnya.

Demikian juga dengan filsafat analitik atau filsafat bahasa yang muncul akibat reaksi dari filsafat sebelumnya, terutama Positivisme sebagai kelanjutan dari Empirisme, yang banyak menggunakan ungkapan-ungkapan yang tidak bermakna (meaningless) dan banyak menggunakan bahasa logika dan ini sangat sulit untuk dipahami. ${ }^{1}$ Karena kebanyakan orang menganggap bahwa bahasa filsafat terlalu berlebihan dalam mengungkapkan realitas sehingga menimbulkan kebingungan bagi para peminat filsafat dan bagi filosof itu sendiri. Dengan demikian tugas filsafat bukan lagi membuat pernyataan yang khusus tetapi memecahkan persoalan yang timbul akibat dari ketidakfahaman terhadap bahasa logika dengan menggunakan kritik terhadap bahasa. Para filosof analitik menganggap bahwa metode ini akan membersihkan dan

${ }^{1}$ Rizal Mustansyir, Filsafat Analitik Sejarah, Perkembangan dan Peranan Para Tokohnya, (Jakarta: PT Grafindo Persada, 1995), h. 6-7 
menyembuhkan pemakaian bahasa dalam filsafat. Salah satu dari tokoh filosof analitik adalah Ludwig Wittgenstein (1889-1951) yang dianggap sebagai salah satu tokoh terbesar dan kompeten dalam bidang analytical philosophy.

Tulisan ini akan membahas pemikiran Ludwig Wittgenstein sebagai salah satu filosof pada abad XX yang mempunyai kontribusi besar terhadap perkembangan filsafat bahasa/filsafat analitik. Filsafat analitiknya yang terkenal dengan permainan bahasa (language game) yang hanya dapat membahasakan gambar seharihari yang digambarkan oleh manusia (Picture teory), sementara ada gambar yang tidak dapat dibahasakan dengan bahasa manusia yaitu gambar Tuhan, oleh karenanya bahasa manusiapun juga tidak bisa membahasakan Tuhan dalam arti yang sebenarnya.

\section{B. Biografi dan Setting Historis ${ }^{2}$}

Ludwig Wittgenstein yang mempunyai nama panjang Ludwig Josef Johann Wittgenstein, dilahirkan di Wina Austria pada tanggal 26 April 1889. Wittgenstein adalah keturunan Yahudi dari kakeknya dan bapaknya yang kemudian masuk Kristen dan ibunya beragama Katolik Roman, ia dibaptis di Gerja Katolik. Ia sangat respek terhadap agama meskipun dia tidak pernah pergi ke Gereja. Ayahnya mempunyai posisi yang terpandang yang mempunyai industri besi dan baja. Dia bungsu dari Sembilan bersaudara dan keempat saudara laki-lakinya, ketiganya melakukan bunuh diri dan saudara laki-lakinya yang lain gugur dalam Perang Dunia ke II sebagai pianis yang terkenal. Dialah satu-satunya harapan bagi orang tuanya dalam meneruskan keluarganya. Hal inilah yang di kemudian hari menjadikan dia depresi dan beberapa kali mencoba bunuh diri, ia mengakui dengan hanya berfilsafat bisa mengatasi penyakitnya tersebut.

Setelah belajar di rumah selama 14 tahun, pada tahun 1906

${ }^{2}$ Biografi ini disimpulkan dari beberapa buku diantaranya adalah: David G. Stern \& Hans Sluga dalam The Cambridge Companion to Wittgenstein, (Cambridge : Cambridge University Press, 1996), h. 1-23: Norman Malcolm, Ludwig Wittgenstein A memoir; Biographical Sketch (Oxford : Oxfod University Press, 1989) , h.1-16 ; Paul Edward, The Ensyclopedy of Philosophy, (London Colher Macmillan Publisher, 1972), h..327, Harold T., M.Smith, R.T. Nolan, Persoalan-persoalan Filsafat, (Jakarta: Bulan Bintang, 1984), h. 370 
ia melanjutkan sekolah di Sekolah Tinggi Tehnik di Linz (Berlin) selama tiga tahun mempelajari mesin dan pada tahun 1908 ia melanjutkan studi tehnik di Universitas Manchester (Inggris) dengan mengadakan penelitian di bidang tehnik pesawat terbang, khususnya mesin jet dan baling-baling. Dia berkeinginan untuk banyak mempelajari matematika karena sekolah tersebut banyak memerlukan pengetahuan tentang matematika dan filsafat matematika. Oleh karena itu ia disarankan oleh Gottlob Frege (ahli matematika jerman) untuk belajar bukunya Bertrand Russel tentang "Prinsip-prinsip matematika", kemudian atas saranya juga ia belajar pada Bertrand Russeldi Cambridge (dosen pada Universitas Trinity) dan Wittgenstein menghabiskan waktunya hanya dalam satu tahun untuk memperoleh predikat yang sempurna. Dia mempunyai predikat yang hampir sama dengan Russel dan G.E. Moore. Russel menggambarkan Wittgenstein sebagai orang yang apostolik ${ }^{3}$ setelah Moore. Russel berumur 17 tahun lebih tua dari Wittgenstein dan 16 tahun dari Moore, tetapi mereka mempunyai kedekatan yang sangat kuat.

Sesudah ayahnya meninggal (1912), ia mewarisi kekayaan ayahnya tapi ia memberikannya kepada orang lain. Ia kemudian hidup di Norwegia mengisolasi diri di sebuah pondok yang ia bangun sendiri. Ketika perang dunia pertama berlangsung, Wittgenstein pulang ke tanah airnya dan masuk menjadi sukarelawan tentara Austria sebagai officer pada tahun 1915. Selama bertahun-tahun ia menulis sebuah buku filsafat yang ia selesaikan pada tahun 1918, ketika itu ia menjadi tawanan tentara Itali, dan naskah buku itu berada di ranselnya. Sewaktu dalam tahanan dia mengirimkan copy dari naskah tersebut kepada Russell dan Frege. Tema-tema tersebut sebelumnya sudah didiskusikan sebelum perang terjadi. Akhirnya dengan perantara Russell ia dibebaskan pada tahun1919 pada bulan Desember, dan pada bulan itu juga ia bertemu dengan Russell di Den Haag. Dalam pertemuan itu ia banyak bertukar pikiran dengan Russell tentang naskahnya dan selanjutnya karya

${ }^{3}$ Yaitu berasal dari bahasa Yunani yang berarti Rasuli, sifat yang menunjukkan kesamaan iman dan praktik Kristiani dalam Gereja sekarang dengan Gereja para Rasul. Syahadat Nikea menunjukkan empat cirri Gereja, yaitu: satu, kudus, katolik dan apostolic, lihat Gerald O’Collins \& Edward G. Farrugia, Kamus Teologi, (Yogyakarta : Kanisius,1996), h.33 
tersebut diterbitkan dalam majalah Annalen der Naturphilosophie pada tahun 1921 dengan judul Logisch-philosophische Abhandlung (ulasan-ulasan logis dan filosofis). Pada tahun 1922 naskah tersebut diterbitkan dalam edisi Inggris disertai teks aslinya dengan judul Tractatus logico-philosophicus yang diberi pengantar oleh Ruseell, akan tetapi Wittgenstein tidak menyetujui kata pengantar tersebut, karena dianggap Ruseell tidak mengerti maksud dari naskahnya. Beberapa catatan yang dibuat saat mempersiapkan naskahnya masih tersimpan dan diterbitkan dengan judul Nootbook 1914-1916. Pada tahun 1923 dia menjadi guru di sekolah Puchberg Austria selama tiga tahun. Pada tahun 1926 dia berhenti menjadi guru dan beralih menjadi tukang kebun di Biara Hutterdolf Wina. Pada tahun 1927 ia melanjutkan kontak dengan teman-temannya seperti Schik, Rudolf Carnap dan Friedrich Weisman (Lingkaran Wina), sampai tahun 1929 dia kembali ke Cambridge untuk melanjutkan kuliahnya dengan menyelesaikan tesis untuk Ph.D dengan karyanya Tractatus yang diuji oleh Moore dan Russell dan ia mulai mengajar di Trinity College pada tahun 1930.

Pada tahun 1935 dia berkunjung ke Rusia dan berpikir untuk menetap di sana dengan harapan jauh dari bentuk kehidupan kekerasan. Akan tetapi kekejaman Stalin menghalanginya. Setelah itu dia mengakhiri kegiatan mengajarnya dan tinggal di pondoknya Norwegia dan menyelesaikan buku yang berjudul Philosophische Untersuchungen atau dikenal dalam bahasa Inggris Philosophical Investigation. Pada tahun 1938 ia diterima sebagai warga negara Inggris dan menggantikan Moore sebagai pofesor. Ketika perang dunia ke II pecah ia menjadi sukarelawan di rumah sakit London. Dia banyak mengkritik filosof-filosof sebelumnya seperti Kant dengan Hume. Dia mendominasi diskusi-diskusi dan tidak ada yang berusaha melawannya, hal inilah yang menjadi alasan mengapa banyak yang tidak menyukainya dan juga pemikirannya sebagai pengaruh yang buruk.

Pada tahun 1947 ia meletakkan jabatannya dan menyelesaikan naskah Philosophical Investigation dan tahun 1949 ia tinggal di Amerika Dalcolm sampai bulan Oktober dan kesehatannya membuat sahabatnya khawatir untuk melanjutkan perjalananya ke Eropa, karena dokter di Cambridge mendiagnosa 
sakit kanker prostat dan tidak yakin akan hidup lama, kemudian dia menghabiskan musim seminya di Wina. Pada bulan April 1950 dia mengunjungi Norwegia pada musim gugur dan tinggal di Oxford sampai februari 1951, dia mengunjungi John Locke yang waktu itu menjadi Rektor tapi ditolak. Pertemuan dengan John Locke tidak sukses, kemudian John Locke mengundangnya tetapi Wittgenstein mengemukakan alasan penolakan undangan tersebut karena dia tidak mampu memberikan kuliah formal pada banyak audien.

Pada tahun 1951 kesehatan Wittgenstein kembali buruk dan dia memutuskan pulang ke Cambridge. Pada tanggal 27 April dia merasa kesakitan dan dua hari kemudian dia meninggal.

Pada dasarnya Wittgenstein selama hidupnya telah mempersembahkan dua buah karya yang bisa disebut magnum opusnya dan mempunyai pengaruh besar dan luas. Kedua buah karya Wittgenstein yaitu Tractatus logico-philosophicus (1921) dan Philosophical Investigation (1953), meskipun kedua buah buku sama-sama karya Wittgenstein tetapi keduanya mempunyai corak yang sangat berbeda. Adanya corak pandangan filosofis yang berbeda itu telah menjadi sumber inspirasi bagi dua aliran filsafat yang berkembang di Inggris yaitu di lingkungan Wina yang mewadahi kecenderungan positivisme logis atau empirisme logis, dan kecenderungan filsafat bahasa.

\section{Pemikiran Ludwig Wittgenstein}

Pengaruh besar mewarnai filsafat bahasa dengan munculnya dua pemikiran yang terkenal yang disebut dengan Wittgenstein I (Tractatus Logico Philosophicus) dan Wittgenstein II (Philosophical Investigation), berikut pemikirannya :

1. Tractatus Logico Philosophicus

Menurut Wittgenstein, terdapat kesalahan memahami bahasa logika dalam merumuskan masalah filsafat, melalui logika dan juga realitas pula ia berusaha untuk menjernihkan kesalahan yang dibuat oleh pendahulunya. ${ }^{4}$ Tugas filsafat kemudian adalah membersihkan seluruh epistimologi dari ungkapan yang bagus

${ }^{4}$ Ludwig Wittgenstein, Tractatus Logico Philosophicus, (London: Routdlege \& Kegan Paul Ltd, 1963), h.27 selanjutnya ia menjelaskan bahwa penyebab utama keracunan bahasa dalam filsafat karena tidak ada barometer yang bias menentukan suatu ungkapan itu bermakna atau tidak. 
tetapi tidak bermakna dari sudut akal sehat seperti halnya dengan emanasi atau kesatuan mistik, hal ini karena salah satu fungsi filsafat adalah menunjukkan sesuatu yang tidak bisa dikatakan atau difikirkan dengan menghadirkan sesuatu secara jelas dan dapat diukatakan. ${ }^{5}$ Dalam hal ini yang ditekankan dalam Tractatus Logico Philosophicus ini adalah problem the limits of language (batasbatas bahasa).

Tesis utama dari Tractatus ini adalah bahwa setiap hal yang dipikirkan harus pula dapat diucapkan. Ketika kita berbicara tentang bahasa sebagai ekspresi pengucapan pikiran, maka pembatasan bahasa juga berarti pembatasan pikiran atau dalam bahasa Wittgenstein: the limits of my language mean the limits of my world. ${ }^{6}$

Wittgenstein membuat satu teori yang disebut sebagai teori gambar (Picture Theory): sebuah teori yang berasal dari pandanganpandangan Russell tentang konsep Isomorfi. Teori ini adalah suatu pandangan yang menganggap adanya hubungan mutlak antara bahasa dan realitas/dunia fakta, yang bisa ditelusuri melalui bagian yang paling elementer, baik dari bahasa maupun realitas. Atau dalam epistimologi, dinamakan sebagai korespondensi antara proposisi dan kedudukan faktual (state of affairs). Dengan cara tersebut bahasa dapat menggambarkan realitas dunia fakta. Proposisi yang merupakan unit terkecil dari bahasa adalah gambaran dari suatu realitas faktual, misalnya ia sedang makan, maka faktanya dia sedang makan, dan terjadilah korespondensi. ${ }^{7}$ Dengan demikian ada dua faktor yang utama dalam teori gambar yaitu proposisi yang merupakan alat dalam bahasa filsafat dan fakta yang ada dalam realitas.

${ }^{5}$ Norman, Malcolm, “Tractatus" in Ludwig Wittgenstein, h.17

${ }^{6}$ Wittgenstein, Tractatus No.5.61 yaitu batas-batas bahasa adalah juga batasbatas pikiran kita, maka yang tidak bias dikatakan dengan bahasa karena tidak ada keadaan faktualnya maka itu tidak dapat dipikirkan. Tidak ada logika tanpa dunia, karena logika sebagai penjelas dari kejadian-kejadian yang ada dunia.

${ }^{7}$ Dijelaskan oleh G.H.Von Wright bahwa teori gambar terletak pada kesesuaian antara unsure-unsur gambar dengan sesuatu dalam realitas, hal inilah yang ditegaskan oleh Wittgenstein, sehingga kita dapat menganalogikan bahwa proposisi itu berfungsi seperti sebuah gambar karena ada hubungan yang sesuai antara unsure-unsur gambar itu dengan fakta. Lebih lanjut baca George Pitcher dalam The Phylosophy of Wittgeinstein, ( New Jerseey :Englewood Clifs, 1964 ), h. 45 
Jika kita dapat memahami hakikat proposisi itu, berarti kita juga dapat mengetahui, mengecek dan melakukan verifikasi yaitu pembuktian kebenaran faktual tersebut. Dengan cara yang sama kita juga bisa melakukan falsifikasi yaitu pembuktian salah. Tetapi bagaimana dengan proposisi yang tidak dapat dikatakan? Wittgenstein mengatakan bahwa "apa yang ada di dunia dapat diutarakan”. Ketika ada epistimologi yang tidak dapat dikatakan maka epistimologi tersebut bersifat tak bermakna alias nonsense. Epistimologi tersebut ingin mengatakan apa yang tidak bisa dikatakan melalui bahasanya. Misalnya pengalaman mistik, dalam kenyataannya tidak pernah bisa ditunjuk secara langsung, karena ia bukan pengalaman inderawi. Jika ada realitas yang bisa diungkapkan dengan kata-kata dan ada juga realitas yang tidak bisa diungkapkan (the unnuterable), terhadap the unnuterable ini perlu diberikan perlindungan, artinya wilayah yang tidak bisa diungkapkan dengan bahasa yaitu wilayah pengalaman mistik adalah wilayah yang sangat penting untuk dimengerti, akan tetapi paradoksnya hal itu tidak bisa dikatakan dengan bahasa. ${ }^{8}$ Bukankah dunia mempunyai makna karena diberi makna oleh sistem bahasa manusia, "The world is part of language, rather than basis". Oleh karena itu maka pengalaman mistik merupakan pengalaman yang hanya dapat ditunjuk dan dialami, tetapi kita tidak bisa berbicara tentangnya karena bahasa kita sendiri juga sifatnya terbatas. Mistis menurut Wittgenstein merupakan pengalaman yang sangat subyektif. Menurut Wittgenstein ada tiga hal yang berbau mistik yang tidak dapat diungkapkan dalam proposisi yaitu Subyek, kematian dan Allah. ${ }^{10} \mathrm{Hal}$ ini bukan berarti dia anti metafisika tetapi menolak hal-hal yang berbau metafisis. ${ }^{11}$ Dari sinilah timbul positivisme logic yang mengadopsi pandangan atomisme logic dan menolak ungkapan

${ }^{8}$ Budhy Munawar Rachman, "Ilmu Hudluri : Mengelah dari mistik? Perihal Epistimologi agama dalam Islam Pluralis, (Jakarta : Paramadina,2000), h.193

${ }^{9}$ Mengutip pendapat Roger Trig dalam Understanding Social Science (Oxford: Basic Blackwell, 1985), h.197. selanjutnya Trig menegaskan bahwa bahasa dan pemikiran membentuk kategori-kategori untuk membangun dan kemudian menafsirkan realitas disekeliling kita.

${ }^{10}$ Menurutnya ketiga hal tersebut tidak bermakna karena melewati batasbatas dunia, oleh karena itu tidak bisa digambarkan dalam bentuk bahasa logika. Lihat Tractatus, No.5\&6

${ }^{11}$ Verhack, "From Metaphhysics...", h.244 
metafisik, teologi, etika dan estetika yang pada hakekatnya tidak mengungkapkan realita empirik.

2. Philosophical Investigation

Buku ini ditulis sebagai kritik terhadap bukunya yang terdahulu yaitu Tractatus Logico Philosophicus yang selanjutnya dipegang teguh oleh kalangan Positivisme Logis. Penolakannya terhadap tiga hal yang utama dalam buku I, pertama, bahwa bahasa dipakai hanya satu tujuan saja, yaitu menetapkan keadaan faktual, kedua, kalimat mendapatkan makna dengan satu cara yaitu menggambarkan suatu keadaan faktual, ketiga, setiap jenis bahasa dapat dirumuskan dalam bahasa logika yang sempurna, walaupun pandangan pertama sulit dilihat. ${ }^{12}$

Dalam Filsafat Investigation ini, Wittgenstein menunjukkan bahwa bahasa mempunyai beberapa fungsi, di mana untuk mengerti fungsi bahasa, perhatian harus dialihkan dari logika dan penyusunan bahasa yang sempurna kepada logika bahasa sehari-hari yaitu bahasa common sense. Atau menjauhi konsep kecenderungan Atomisme Logis dan beralih ke arah pandangan George Moore yang berfilsafat tentang common sense (akal sehat) yang menekankan bahwa arti ekspresi apa saja yang sangat tergantung pada penggunaan bahasanya, yang kemudian dikenal dengan istilah meaning in use. ${ }^{13}$ Bahasa logis hanya menempati satu lokasi saja dalam keseluruhan apa yang bisa dilakukan oleh bahasa. Masih ada pengungkapan yang lain, misalnya ucapan-ucapan performatif (performatifutterece), suatu istilah yang berasal dari Joh L. Austin yang menganggap ucapan ini bukan merupakan bahasa deskriptif melainkan speech-act atau suatu tindak bahasa. Tema yang popular dalam Filsafat Investigation adalah Language Games (permainan bahasa) yang berujud dalam berbagai

${ }^{12}$ K. Bertens, Ringkasan Sejarah Filsafat, (Yogyakarta: Yayasan Kanisius, 1975). h. 48

${ }^{13}$ Ian G. Barbour, Issues in Science and Religion (New York : Harper \& Row, Publisher, 1971), h.243-4, dikatakan juga bahwa makna dari term permainan bahasa dan bentuk-bentuk kehidupan meupakan pemahaman terhadap aplikasi dari konsep pada kasus-kasus yang spesifik dari bahasa agama dan kehidupan keberagamaan, yaitu ide-ide tentang agama, magic dan ritual dalam hubungannya dan hubungan dengan ilmu pengetahuan sangat berpengaruh. Lihat Stephen A. Strais, "Wittgenstein and The Philosophy of Region , h.507 
ragam bentuk-bentuk kehidupan (forms of life). ${ }^{14}$ Karena Language Games inilah maka bahasa mempunyai berbagai macam penggunaan, tergantung dari konteksnya, istilahnya meaning is context, dengan menggunakan bahasa kita dapat bermain dengan beragam permainan, yaitu ketika beralih dari suatu cara bahasa kepada cara yang lain. ${ }^{15}$ Dan setiap bahasa itu mempunyai aturan sendiri yang tidak bisa dicampur-adukkan karena masing-masing mengandung ketentuan yang mencerminkan bentuk dari permainan bahasa yang bersangkutan. ${ }^{16}$ Wittgenstein menganggap bahwa makna sebuah kata tergantung pada penggunaaan dalam kalimat sementara makna kalimat tergantung penggunaannya dalam bahasa, akan tetapi kata yang sama apabila digunakan didalam language game yang berlainan, bisa berarti berbeda walaupun memiliki kemiripan keluarga (family resemblance). ${ }^{17}$

Menurut Wittgenstein, bahasa filsafat telah mengalami kekacauan karena para filosof yang tidak menggunakan aturan permainan bahasa, hal ini menyebabkan bahasa filsafat menjadi lemah, karena ada tiga alasan, ${ }^{18}$ yaitu pertama, penggunaan istilah bahasa filsafat yang tidak sesuai dengan permainan bahasa, seperti penggunaan kata pengetahuan, obyek, proposisi dan lain-lain yang mencoba menjangkau hakikat. Kedua, adanya pencarian kesatuan pengertian dalam keanekaragaman, kesamaan dalam pebedaan, ketunggalan dalam kemajemukan (craving for generality). Ketiga, penyamaran pengertian melalui pengajuan istilah yang tidak dapat dipahami, seperti eksistensi (keperiadaan), ketiadaan, dll. Sehingga tugas filsafat tidak menarik kesimpulan tetapi menyatakan apa yang dapat diterima setiap orang atau menjelaskan persoalan filsafat dengan bahasa yang dapat dimengerti dengan digambarkan

${ }^{14}$ Ludwig Wittgenstein, Philosophical Investigation, trans. G.E.M. Anscombe (New York : Macmillan, 1984), h.11

${ }^{15}$ Adanya pluriformitas (keanekaragaman) bahasa yang dijumpai dalam kehidupan sehari-hari yang meliputi jenis-jenis kata dan kalimat, sepeti menari, bekerja, bertanya, menjawab soal dan lain-lain, lihat Wittgenstein dalam Filsafat Investigation, h. 23

${ }^{16}$ Rizal Mustansyir, Filsafat Analitik..., h.103-4

${ }^{17}$ Ibid, h.105

${ }^{18}$ Wittgeinstein,philosophical.....,h.38-67 
secara deskriptif menggunakan bahasa sehari-hari ${ }^{19}$ dan tidak ikut memberikan penafsiran tentang realitas, memaparkan apa adanya mambiarkan segala sesuatu terjadi sebagaimana apa adanya. ${ }^{20}$

Dengan demikian segala sesuatu yang berbau metafisika, seperti Tuhan menurutnya adalah mistik dan tidak perlu ditafsirkan, karena Tuhan bukanlah obyek fisik yang terbatas, Tuhan bukanlah sebuah nama barang, Tuhan merupakan semangat dan bukan fisik. ${ }^{21}$ Ketika penganut agama mengatakan bahwa Tuhan menciptakan surga dan bumi, Tuhan mengangkat Jesus dari kematian atau Tuhan mengabulkan permohonan kesembuhan, ini mengimplikasikan bahwa ada konektisitas antara bahasa agama dan bahasa yang kita gunakan untuk mendiskripsikan secara alami, sejarah dan kehidupan kita sehari-hari. ${ }^{22}$

\section{Implikasi dari Pemikiran Wittgenstein}

Ada beberapa implikasai dari pemikiran Wittgenstein yang dapat kami uraikan di sini yaitu pertama dari pemikiran Wittgenstein I yang menimbulkan aliran baru setelah atomisme logis yaitu positivisme logis, aliran ini merupakan aliran yang semula terkenal dengan Lingkaran Wina yang didirikan th. 1922 oleh Moritz Schlick yang cenderung terhadap sesuatu yang positif dan pasti, serta dapat dipertanggung jawabkan secara ilmiah. ${ }^{23}$ Pemikiran yang mendasar adalah penolakan terhadap metafisika, teologi dan etika, hal ini karena ketiga hal tersebut tidak bisa dibuktikan dengan fakta empiris dan juga relativis atau tidak bisa diukur, dianalisa dan dibuktikan kebenarannya. ${ }^{24}$ Teori ini sebetulnya mengacu pada Tractatus yang menyatakan bahwa segala yang berbau metafisik tidak bisa dibahasakan (Atomisme Logis).

${ }^{19}$ Clack, Brian R, "Dz, Philips, Wittgenstein \& Religion”, in The Religious Studies, No.31, 1993, h.3

${ }^{20}$ Ibid, h..109

${ }^{21}$ Kriteria Tuhan dapat ditemukan dalam tradisi-tradisi agama seperti Yahudi, Kristen, Islam, menurut mereka Tuhan merupakan obyek realitas, keberadaannya merupakan fakta supernatural, lebih lanjut baca : Wittgenstein and the Philosophy of Religion, Oleh Setephen A. Satris, h. 507-8

${ }^{22}$ Stepphen Evans,Philosophy of.......,h.153

${ }^{23}$ Rizal Mustansyir,Filsafat....., h.78

${ }^{24}$ Amsal Bahtiar,Filsafat...., h.115-6 
Implikasi yang kedua merupakan jawaban atas filsafat yang dikemukakan oleh Wittgenstein baik dalam Tractatus maupun Philosophical Investigation tentang hal-hal yang berkaitan dengan mistik. Jawaban ini dikemukakan oleh filosof Muslim Mehdi Hairi Yazdi tentang ilmu Khuduri. Mehdi sepakat dengan apa yang dikemukakan dalam tractatus yaitu tentang batas-batas bahasa dan juga dengan teori gambar, akan tetapi, ada pengetahuan yang tidak bisa dijelaskan oleh teori gambar, yang disebut dengan pengetahuan dengan kehadiran (ilmu khuduri). ${ }^{25}$ Pada akhirnya Wittgenstein dengan pengetahuan - dengan - korespondensi. Pengetahuan dengan - Kehadiran adalah pengetahuan yang nyata bagi subyek yang mengetahui, secara performatif, langsung tanpa perantara representasi mental atau simbolisme kebahasaan apapun, subyek ini dilihat sebagai "aku performatif" yang pada tingkat tertinggi akan membawa pada pengalaman mistis yang mempercepat proses titik puncak kesadaran kesatuan diri yaitu kesatuan ekstensi mutlak dengan Tuhan (wahdatul wujud). ${ }^{26}$ Tema inilah yang memberi jawaban atas kegelisahan Wittgenstein dalam usahanya mengetahui Tuhan, tujuan hidup, dan makna dunia. Mehdi terus berusaha melewati problem filosofis Wittgenstein yang menjadi dasar pemikirannya. Usaha-usaha yang dilakukan Mehdi adalah memberikan penjelasan tentang adanya banyak language games dalam struktur pengetahuan manusia diantaranya adalah menjelaskan struktur epistimologis language game dari pengalaman mistik. ${ }^{27}$ Menurutnya pengalaman mistik itu adalah suatu yang dapat dikomunikasikan atau dituliskan filsafatnya, tidak seperti Wittgenstein. Menurutnya pengalaman mistis dapat dipahami dengan pembedaan kategoris, ${ }^{28}$ pertama, mistisme yang tidak bisa diceritakan, merupakan pengalaman mistis yang tidak bisa dikonseptualisasikan dalam term-term pemahaman masyarakat umum.

Dan karena itu tidak memiliki bahasa yang lazim dipahami masyarakat; kedua, mistisme introspektif dan rekonstruktif sebagai bahasa murni mistisme; ketiga, meta-mistisme filosofis yang

${ }^{25}$ Budhy Munawar Rachman,”Ilmu Khudluri...”, h.205

${ }^{26}$ Mehdi Ha'iri Yazdi, Пmu Khudluri : Prinsip-prinsip Epistimologi dalam filsafat Islam, dari Suhrawardi via Wittgenstein, (Bandung : Mizan, 1994), h.2-3

${ }^{27}$ Ibid, h.215

${ }^{28}$ Ibid, h. 238-9 
berbicara tentang mistisme, inilah yang menjadi dasar bahasa $I l m u$ Khuduri

Implikasi ketiga berasal dari pemikiran Wittgeinstein II, yang memberikan inspirasi bagi kaum postmodernis. Salah seorang tokohnya yang terkenal adalah Jean Francois Lyotard yang mendapat pengaruh kuat dari Wittgenstein tentang language game-nya sebagai paradigma untuk menganalisa masyarakat industrial, diantara ide pemikirannya adalah penolakan terhadap tradisional yang menekankan kesatuan, menurutnya pasca modern merupakan pembebasan ke arah pluralitas bentuk-bentuk kehidupan, heteromorf, nonreduktif dan harus lebih berorientasi pada instabilitas, paralogi, diskontinuitas, ini merupakan pengaruh dari konsep keanekaragaman permainan bahasa; kemudian Lyotard juga mengarah kepada analisa kehidupan sehari-hari yang dipandang sebagai alternative positif terhadap teori global, ini sesuai dengan pragmatika bahasa yang dipakai Wittgenstein II; serta penerapan konsep permainan bahasa untuk menjelaskan berbagai macam fenomena kehidupan dunia industrial modern. ${ }^{29}$

Sebetulnya implikasi tersebut tidak hanya mempengaruhi pada aliran, atau tokoh yang tersebut diatas tetapi juga tokoh-tokoh filosofi lain dan mungkin kita juga akan terpengaruh dengannya. Menurut Brian R. Clack menyatakan bahwa ada lima tesis yang menyebabkan keterpengaruhan Wittgenstein dalam filsafat agama ${ }^{30}$ yaitu, 1) kepercayaan keagamaan adalah sebuah logika yang diambil dari aspek-aspek kehidupan manusia, 2) kepercayaan terhadap agama hanya dimengerti oleh para penganut agama, 3) apa saja yang disebut sebagai bahasa agama ditetapkan apakah bermakna atau tidak, 4) kepercayaan agama tidak dapat dikritisi, 5) kepercayaan agama tidak dapat dipengaruhi oleh personal, sosial, ataupun kurtural. Inilah yang menimbulkan kontroversi dan kritikan. Sebagaimana yang diungkapkan oleh Kai Nielsen yang menganggap bahwa Wittgenstein termasuk fideisme ${ }^{31}$ karena

\footnotetext{
${ }^{29}$ Rizal Mustansyir, Filsafat...., h.11-112

${ }^{30}$ Brian R. Clack, “ Dz. Phplips : Wittgenstein and Religion ”, in The Religion Studies, No.31, 1995, h.5-15

${ }^{31}$ Fideisme yaitu kecenderungan untuk merendahkan peranan budi dalam menguji tuntutan-tuntutan keagamaan dan juga terlalu menekankan keputusan-bebas iman. Fideisme ini dapat menentang orang untuk berusaha
} 
mengubah bahasa agama menjadi sebuah kedudukan yang tinggi dengan kriteria makna dan kebenaran. ${ }^{32}$ Dan juga kritisme modern yang menuduh Wittgenstein telah melindungi kepercayaan terhadap agama sehingga melawan kritisme, sehingga Wittgenstein diduga sebagai orang yang anti intelektualisme dan konservatif. ${ }^{33}$

\section{E. Penutup}

Seperti yang diuraikan di atas bahwa Wittgenstein merupakan peletak dasar pemikiran yang kuat yang bercorak logosentris mencoba untuk membuat netralitas metode analisisnya. Dalam usahanya mengetahui tentang Tuhan, tujuan hidup dan makna dunia, dengan tractacusnya, dia hanya berdiam diri dan juga dengan Philoshophical Investigationnya ia juga tidak memberikan suatu ajaran, hanya saja ia memberikan kita tentang kesadaran bahwa ada jalan, atau language game dari suatu bentuk kehidupan yang bisa menjelaskan kepada kita tentang Tuhan, tujuan hidup dan makna dunia, tetapi ia tidak memberikan bentuknya seperti apa, mungkin inilah yang dinamakan mistik.

Dilihat dari uraian di atas ada pertanyaan yang perlu diajukan disini yaitu sejauhmana manusia dapat mengetahui Tuhan yang transenden dan absolute ? Bagaimana pengetahuan manusia yang benar tentang Tuhan? Jika Tuhan tidak dapat dinamai, dibicarakan dan diungkapkan, bagaimana mungkin manusia dapat mengetahui dan berhubungan dengannya ?

Kepercayaan terhadap Tuhan ditentukan dan diwarnai oleh kapasitas pengetahuan sang hamba. Kapasitas pengetahuan itu tergantung kepada masing-masing invididu. Dengan demikian Tuhan yang diketahui oleh hamba adalah Tuhan yang diketahui dan dipercayainya. Tuhan kepercayaan adalah gambar atau bentuk

mempertanggungjawabkan kebenaran iman secara ilmiah, tetapi juga dapat memandang iman sebagai loncatan buta kedalam kegelapan, Gerald O' Collins \& Edward F., Kamus Theologi, h.79-80

${ }^{32}$ Seperti pernyataan “ Tuhan exist”, pertanyan apakah Tuhan benar-benar nyata? Padahal term Tuhan digunakan oleh komunitas manusia sebagai nama untuk realitas, benarkah Tuhan nyata? Konsep generalisasi tentang nyata inilah yang diabstrasikan dari sebagian permainan bahasa yang memberikan makna, lihat, Stephen Evans, Philosophy of....., h.153

${ }^{33}$ Brian R. Clack, D.Z. Philips....., h.4 
Tuhan, atau pemikiran, konsep, ide, gagasan tentang Tuhan yang diciptakan oleh akal manusia. ${ }^{34}$ Tuhan ini bukanlah Tuhan yang sebenarya. Tuhan yang sebenarnya adalah Tuhan pada diri-Nya, Zatnya yang tidak diketahui dan tidak dapat diketahui oleh akal manusia, The Real of God, Tuhan yang munazzah atau tidak dapat dibandingkan dengan alam seisinya. Inilah yang manjadi persoalan bagi para filosof, teolog, mistikus yaitu "mengatakan apa yang sesungguhnya tidak dapat dikatakan", "membicarakan apa yang tidak dapat dibicarakan", "mengetahui apa yang tidak dapat diketahui", "menamai yang tidak dapat dinamai", "mengungkapkan apa yang tidak dapat diungkapkan" ${ }^{35}$

Salah satu cara terbaik untuk menyelesaikan persoalan ini adalah dengan suatu teologi apofatik yaitu teologi tidak mengetahui (the theology of unknowing), yang melukiskan pengalaman transenden tentang Tuhan dalam cinta sebagai suatu "mengetahui dengan tidak mengetahui" ("knowing by unknowing")dan suatu "melihat yang bukan melihat" (seeing that is not seeing). ${ }^{36}$

Dari uraian di atas dapat disimpulkan bahwa Wittgenstein mencoba untuk tidak mendefinisikan tentang hal-hal yang berbau metafisik karena ungkapan-ungkapan tentang hal tersebut tidak akan terjangkau dengan kata-kata yang dibuat oleh manusia dan memang tidak biasa. []

\section{Daftar Pustaka}

Barbour, Ian G., Issues in Science and Religion, New York : Harper \& Row, Publisher, 1971.

Bertens, K., Ringkasan Sejarah Filsafat, Yogyakarta : Yayasan kanisius, 1975.

${ }^{34}$ Kautsar Azhari Noer, "Tuhan yang Diciptakan Dan Tuhan yang Sebenarnya”, dalam Paramadina, Vol.I, No.1, Juli-Desember, 1998, selanjutnya, bahwa Tuhan yang demikian adalah Tuhan yang diciptakan manusia berdasarkan kemampuan, pengetahuan, penangkapan dan persepsinya,.

${ }^{35}$ Ibid, h.141-2

${ }^{36}$ Thomas Merton,loc.cit.Kata apofatik (apophatik) digunakan oleh Dionysius yang membicarakan teologi negative, sebagai lawan teologi positif. 
Clark, Brian R, "Dz, Philips, Witgenstein \& Religion" dalam The Religious Studies, No. 31, 1993.

Edward, Paul, The Ensyclopedy of Philosophy, London Colher Macmillan Publisher, 1972.

Harold T., M. Smith, R.T. Nolan, Persoalan-persoalan Filsafat, Jakarta: Bulan Bintang, 1984.

Malcolm, Norman, Ludwig Wittgenstein A memoir; Biographical Sketch, Oxford : Oxfod University Press, 1989.

Mustansyir, Rizal, Filsafat Analitik Sejarah, Perkembangan dan Peranan Para Tokohnya, Jakarta: PT Grafindo Persada, 1995.

Noer, Kautsar Azhari, "Tuhan Yang Diciptakan dan Tuhan Yang Sebenarnya”, dalam Paramadina Volume I, Nomor. 1, Juli Desember 1998.

O'Collins, Gerald \& Farrugia, Edward G., Kamus Teologi, Yogyakarta : Kanisius,1996.

Pitcher, George, dalam The Phylosophy of Wittgeinstein, New Jerseey: Englewood Clifs, 1964.

Rachman, Budhy Munawar, Islam Pluralis, Jakarta : Paramadina, 2000.

Stern, David G. \& Sluga, Hans, The Cambridge Companion to Wittgenstein, Cambridge : Cambridge University Press, 1996.

Trig, Roger, Understanding Social Science, Oxford: Basic Blackwell, 1985.

Yazdi, Mehdi Ha'iri, Ilmu Khudluri : Prinsip-prinsip Epistimologi dalam filsafat Islam, dari Suhrawardi via Wittgenstein, Bandung : Mizan, 1994.

Wittgenstein, Ludwig, Philosophical Investigation, trans. G.E.M. Anscombe, New York : Macmillan, 1984. , Tractatus Logico Philosophicus, London: Routdlege \& Kegan Paul Ltd, 1963. 